\title{
Delineation of Fast Flow Paths in Porous Media Using Noble Gas Tracers
}

\author{
G. Bryant Hudson, J. E. Moran
}

March 21, 2002

U.S. Department of Energy

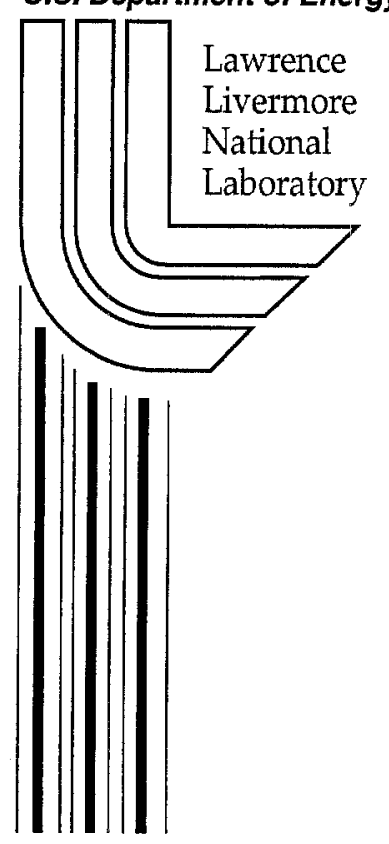




\section{DISCLAIMER}

This document was prepared as an account of work sponsored by an agency of the United States Government. Neither the United States Government nor the University of California nor any of their employees, makes any warranty, express or implied, or assumes any legal liability or responsibility for the accuracy, completeness, or usefulness of any information, apparatus, product, or process disclosed, or represents that its use would not infringe privately owned rights. Reference herein to any specific commercial product, process, or service by trade name, trademark, manufacturer, or otherwise, does not necessarily constitute or imply its endorsement, recommendation, or favoring by the United States Government or the University of California. The views and opinions of authors expressed herein do not necessarily state or reflect those of the United States Government or the University of California, and shall not be used for advertising or product endorsement purposes.

This report has been reproduced directly from the best available copy.

Available electronically at http://www.doc.gov/bridge

Available for a processing fee to U.S. Department of Energy And its contractors in paper from

U.S. Department of Energy

Office of Scientific and Technical Information

P.O. Box 62

Oak Ridge, TN 37831-0062

Telephone: (865) 576-8401

Facsimile: (865) 576-5728

E-mail: reports@adonis.osti.gov

Available for the sale to the public from

U.S. Department of Commerce

National Technical Information Service

5285 Port Royal Road

Springfield, VA 22161

Telephone: (800) 553-6847

Facsimile: (703) 605-6900

E-mail: orders@ntis.fedworld.gov

Online ordering: http://www.ntis.gov/ordering.htm

\section{OR}

Lawrence Livermore National Laboratory

Technical Information Department's Digital Library

http://www.Ilnl.gov/tid/Library.html 


\title{
Delineation of Fast Flow Paths in Porous Media Using Noble Gas Tracers
}

\author{
By G. Bryant Hudson and Jean E. Moran
}

Analytical and Nuclear Chemistry Division, Lawrence Livermore National Laboratory, Livermore, CA 94551, USA

\begin{abstract}
Isotopically enriched xenon isotopes are ideal for tracking the flow of relatively large volumes of groundwater. Dissolved noble gas tracers behave conservatively in the saturated zone, pose no health risk to drinking water supplies, and can be used with a large dynamic range. Different Xe isotopes can be used simultaneously at multiple recharge sources in a single experiment. Results from a tracer experiment at a California water district suggests that a small fraction of tracer moved from the recharge ponds through the thick, unconfined, coarse-grained alluvial aquifer to high capacity production wells at a horizontal velocity of $6 \mathrm{~m} /$ day. In contrast, mean water residence times indicate that the average rate of transport is 0.5 to $1 \mathrm{~m} /$ day.
\end{abstract}

\section{INTRODUCTION}

In some areas of the arid western USA, water purveyors use artificial recharge to augment natural recharge to groundwater basins where water demand is high. In coastal regions of California, USA, artificial recharge replenishes basins that were subject to overdraft, mitigates seawater intrusion, and provides benefits to water quality. Artificial recharge facilities may consist of abandoned quarries or injection wells, with downgradient production wells that are used for public water supply. Source water for artificial recharge may be water captured from the watershed, imported water, or recycled wastewater. For the latter case, the proposed regulations in California for the potability of water of wastewater origin stipulate a minimum subsurface residence time of six months to one year and dilution of $\geq 50 \%$ with a non-wastewater source (Asano, 1993).

In order to demonstrate compliance to the proposed regulations, and to improve the understanding of groundwater flow in the affected basins, a tracer may be added to the artificial recharge source water. Movement of the tracer is then monitored at downgradient points in the groundwater basin. In practice, the period of observation is on the time scale of several months to a couple of years; shorter than for natural or bomb pulse isotopic tracers such as ${ }^{3} \mathrm{H}$ or ${ }^{14} \mathrm{C}$. The data acquired from such a tracer experiment can be used to calibrate groundwater flow models and to identify fast flow paths.

Delineation of fast flow paths is important, because the portion of water that travels most quickly from surface sources to production wells may have the greatest impact on water quality. The tracer data are particularly useful when used in combination with groundwater age dating, which gives a measure of the mean, integrated transport time. In particular, the tritium-helium method of groundwater dating is useful for subsurface 
residence times of one to fifty years. The tracer data then allow more detailed interpretation of the transport of groundwater on a one to two year time scale.

\section{BACKGROUND AND METHODS}

\section{Water District Facilities}

The Alameda County Water District (ACWD), in the East San Francisco Bay area of northern California artificially recharges $2.5 \times 10^{10} \mathrm{~L}$ of water per year. Recharge facilities consist of several abandoned quarries ranging in volume from $1.2 \times 10^{8} \mathrm{~L}$ to $3.3 \times 10^{9} \mathrm{~L}$, and of temporary reservoirs impounded behind inflatable rubber dams, in a creek channel that is adjacent to recharge ponds (Figure 1).

The groundwater basin comprises alluvial deposits of the Quaternary period. Between periods of alluvial deposition, sea levels in San Francisco Bay rose and finegrained sediment settled out to form aquicludes, separating the sands and gravels into distinct aquifer layers. The Hayward Fault, part of the San Andreas system, runs in a general north-south direction in the area, and hydraulically divides the groundwater basin into two sub-basins: the "Above Hayward Fault" (AHF) and "Below Hayward Fault" (BHF) sub-basins on the east and west side of the Hayward Fault, respectively (Figure 2). Also shown in Figure 2 are Tritium-helium groundwater ages (Schlosser et al., 1988, Solomon et al., 1992, Ekwurzel et al., 1994) determined as part of this study, which give a measure of the mean residence time since recharge of the water drawn from those wells.

With the Hayward Fault to the west, and hills to the north, south, and east, the AHF sub-basin is effectively contained by no-flow boundaries. The aquifer is unconfined throughout the study area, and no major changes in lithology have been observed during drilling of wells. The BHF sub-basin comprises three major regional aquifers, which are separated from each other by the aforementioned clay aquicludes (Figure 2). The aquifers include the shallow Newark Aquifer, the Centerville-Fremont Aquifer and the Deep Aquifer. Throughout the basin, the Centerville-Fremont and Deep Aquifers are confined. The Newark Aquifer is unconfined near the recharge area and the production wellfield but is confined in other areas. All three major aquifers in the BHF sub-basin are hydraulically bounded to the east by the Hayward Fault.

The water district operates 17 high volume production wells that are situated between 370 and $760 \mathrm{~m}$ from the recharge ponds (Figure 1). Production wells in the AHF sub-basin produced $1.85 \times 10^{10} \mathrm{~L}$ of water over the study period, and provide the main sink for water in the sub-basin. BHF wells produced $1.2 \times 10^{10} \mathrm{~L}$ of water, with flow toward distal parts of the basin and up into creeks providing other sinks for water in the sub-basin. In contrast to two well documented tracer studies conducted at the Borden and Cape Cod aquifers (McKay et al., 1986; LeBlanc et al., 1991), which used several hundred multi-port wells installed for the purpose of the studies, this experiment used only existing infrastructure. Approximately $40 \%$ of all of the water delivered to customers in the area is groundwater. Major issues that are related to artificial recharge are the potential for contamination from spills into the creek that supplies the recharge ponds, changes to water quality during recharge and subsurface flow, and compliance with potential regulations related to the use of recycled wastewater. 


\section{Experimental}

In the experiment described here, artificial noble gas tracers were added to three of the recharge ponds, shown in Figure 1, and movement of the tracer was monitored in the groundwater wells shown, over a period of one year. The fact that multiple surface water sources supply public drinking water wells dictated the choice of tracers. Dissolved noble gases are chemically inert, colorless and odorless, and are nonradioactive, thereby posing no real or perceived health risks. By using tracers of the same element enriched in different isotopes, recharge from multiple sources can be examined using a single noble gas isotopic analysis from a well water sample.

Furthermore, the low natural abundance of certain isotopes of naturally-occurring dissolved noble gases means that by using even a small volume of tracer with a highly altered isotopic content, a large dynamic range can be achieved during dilution with native groundwater. Dissolved noble gases do not sorb to aquifer materials and are not retarded relative to water flow. The only difference in saturated zone transport properties between water molecules and dissolved noble gases is diffusion, but this is a negligibly small effect under the conditions that apply.

Xenon has nine stable isotopes, five of which are good candidates for isotopically enriched tracers. Figure 3 shows the natural abundance pattern for $\mathrm{Xe}$, along with the isotopic composition of two of the tracers used in this study. Isotopically enriched noble gases are available commercially. Tracer gas is pre-dissolved into a small volume (a few liters) of water for introduction into the recharge water body.

Dissolved ${ }^{124} \mathrm{Xe}$ tracer was loaded into Bunting Pond and ${ }^{136} \mathrm{Xe}$ tracer was loaded into Kaiser Pond (Figure 1 and Figure 4). Tracer was released by gravity flow through a plastic tube, in one location near the center of the pond, at a depth of $6 \mathrm{~m}$ (Bunting Pond) and $7.5 \mathrm{~m}$ (Kaiser Pond). The process of tracer introduction was repeated once per week for four weeks. The rationale for introducing tracer over a period of four weeks was to provide a tracer pulse in wells such that sampling could be spaced at reasonable time intervals.

Sampling for dissolved noble gases in water is accomplished by pumping the water through a $3 / 8$ " copper tube under pressure (so that the gases stay in solution), and pinching the tube at both ends with metal clamps, to make an air-tight seal (e.g., Sanford et al., 1996). Analysis of the dissolved tracer gases is by noble gas mass spectrometry with sample introduction by multi-port gas handling manifold. The precision for ${ }^{124} \mathrm{Xe} /{ }^{132} \mathrm{Xe}$ is $0.7 \%$ and the precision for ${ }^{136} \mathrm{Xe} /{ }^{132} \mathrm{Xe}$ is $0.1 \%$. For the tracer volume loaded in this experiment, detection of $1 \%$ of the surface water of maximum tracer concentration $\left(\mathrm{C} / \mathrm{C}_{0}=1 \%\right)$ was possible.

\section{RESULTS AND DISCUSSION}

\section{Tracer in Surface Water}

Field measurements of the pond water (temperature, conductivity, oxidation/reduction potential) did not show significant variation with depth. The lack of 
an observed thermocline suggests that the tracer would become well mixed in a period of time that is short compared to the infiltration rate. Loss of tracer in the surface water occurs by recharge to the aquifer and by diffusion at the water/air interface. This latter process is the main disadvantage of using dissolved noble gas tracers in surface water bodies, i.e., the amount of tracer that is lost at the water/air interface in the surface water may not be well known. (A more robust experiment would involve introduction of the tracer at injection wells in the saturated zone.)

While measurements from samples from the same depth at different locations in the pond showed that thorough lateral mixing did take place (Figure 4), the samples from different depths in both ponds showed wide variation. Throughout the course of monitoring surface water concentrations, deeper samples had higher concentrations of tracer than shallow samples. The very slow loss of tracer, over the six week period of observation after the first tracer introduction, was also unexpected. We postulate that the pond recharge is controlled not by hydrologic parameters, but rather by characteristics of the pond sediments, and that the variability in recharge through the walls of the ponds results in the stratification observed in tracer concentration.

Rates of percolation from the AHF ponds did not correlate significantly with monitoring well levels or with the head differential between surface water and groundwater. Moreover, percolation rates were not related to wellfield pumping, although water levels recorded at monitoring wells within only several meters of the ponds did fluctuate in response to pumping. The rate of percolation correlated weakly with surface water levels alone $\left(\mathrm{R}^{2}=0.2\right)$, and more $\left(\mathrm{R}^{2}=0.5\right)$ with the rate of surface water inflow to the ponds. These correlations and the observed large difference between surface water levels and water levels in nearby monitoring wells, suggest that there is relatively insignificant groundwater seepage through the pit bottom or through the deep portions of pit sidewalls, which are in direct contact with groundwater. There is a substantial component of the pond water column that is above groundwater levels, and seepage is evidently more appreciable above the groundwater level. More specifically, we postulate that when surface water is diverted into the pond, it percolates fastest through the portion of the sidewall surface that was above the pond level (and exposed to air and sunlight) just prior to the inflow event.

It appears that shallow pit wall permeability, therefore, is both a depth-dependent and time-dependent phenomenon in these recharge ponds. We postulate that submergence enables deposition of fine sediment or a biofilm to develop on the sidewall surface inside the pond, reducing permeability in the process. But after the water level drops and the previously submerged part of the wall is dried and exposed to sunlight, the biofilm may break up and/or fine-grain sediment may dry and crack, restoring wall permeability to some degree (e.g., Warner et al., 1994).

At depths where the wall is always submerged, permeability is likely to be maintained at a constant, low value. A grab sample of sediment from the bottom of Bunting pond at a depth of about 20 feet had the following characteristics: sediments are very fine grained and very dark in color with a strong smell of reduced sulfur. Given that the waters in the ponds have dissolved oxygen levels close to saturation, one would not expect to see strongly reducing conditions in sediments where oxygenated waters were percolating. These observations provide further evidence that percolation is minimal in deeper parts of the ponds. 
The release of tracer from the pond to groundwater may therefore be controlled by diffusion of tracer from the hypolimnion to the epilimnion, assuming that all flux to groundwater occurs from the epilimnion. In other words, in this engineered system, in which water is delivered at irregular intervals via large diameter pipes, the ponds are not completely mixed, and surface water entering them short-circuits through the epilimnion en-route to infiltration to groundwater, without mixing with deeper pond water. Along the way, the water fluxing through the epilimnion picks up small amounts of tracer diffusing upward to the shallow, low concentration zone. This explains the observation that tracer concentrations are higher in the deeper parts of the lake than in the shallower parts. Although examination of surface water dynamics was not one of the goals of this tracer experiment, variable recharge in heterogeneous sediments is inferred from the observed tracer distribution.

\section{Tracer in Groundwater}

Tracer elution curves for several monitoring and production wells are shown in Figures 5 and 6. Determination of the initial tracer concentration, $\mathrm{C}_{0}$, is complicated by the issues discussed above, regarding the spatial and temporal variability in recharge through the sides of the ponds. One monitoring well (21L08 in Figure 4), adjacent to Kaiser Pond had a maximum ${ }^{136} \mathrm{Xe}$ tracer concentration that closely matched the maximum concentration observed in the shallow section of the pond. That value was chosen for $\mathrm{C}_{0}$ for ${ }^{136} \mathrm{Xe}$ tracer. Likewise, the maximum value observed for the shallow water 'curve' for ${ }^{124} \mathrm{Xe}$ tracer in B Pond is used as the value for the initial concentration for the curves in Figure 6. Table 1 gives arrival times for the leading edge and center of mass of the tracer for the wells where tracer was detected. Flow rates shown in Table 1 are simple $\mathrm{v}=\mathrm{x} / \mathrm{t}$ calculations, with distance measured from a map made with Global Positioning System locations for wells and surface water bodies.

The most striking features of the tracer curves and travel times are 1) the very short travel time for a small fraction of the water pumped at some of the production wells, 2) the wide differences in tracer curve shapes, including the lengths of the tails for wells in close proximity to each other, and 3) the low tracer concentrations observed at nearly all the wells. Two of the production wells, in the middle of the wellfield, intercepted both Xe tracers.

The short travel time ( 60 to 300 days) to the production wells indicates a maximum velocity of approximately $6 \mathrm{~m} /$ day (Table 1 ). This value does not represent the velocity of the center of mass, but rather is the rate of travel for that portion of the surface water with detectable tracer that reaches the wells fastest. Travel times for the tracer peaks are also reported in Table 1. Mean, integrated travel times, based on the water age from the tritium $-{ }^{3} \mathrm{He}$ age dates, are about 10 times lower, or $0.5 \mathrm{~m} /$ day.

Given the low gradient (.0015), and low pumping volume $\left(2 \times 10^{6} \mathrm{~L}\right.$ for AHF wells) over the first sixty days of the tracer study, the fast arrival was somewhat unexpected. Compared to groundwater velocities determined at the well-studied Cape Cod, Massachusetts (LeBlanc et al., 1991) and Borden, Ontario sites (MacFarlane et al., 1983 ), which were $5-90 \mathrm{~m} / \mathrm{yr}$ and $180-440 \mathrm{~m} / \mathrm{yr}$ respectively, the horizontal velocity measured here is 5 to 25 times greater. A combination of high permeability sediments, heterogeneous sediments with high hydraulic conductivity layers, and a high degree of 
horizontal dispersivity leads to the observed high velocity for a small fraction of the groundwater. Tracer results from the BHF sub-basin, where confined aquifers are separated by clay aquicludes, showed slower water movement, with no tracer detections in the production wellfield in that sub-basin over an 18 month period.

This fast travel time indicates that contaminants that are not retarded relative to water flow will reach water supply wells quickly, before remediation methods are in place. Furthermore, de-activation of viruses may require longer time periods in the subsurface (Gerba, 1999) than the travel time observed here.

Because of limitations in sampling points (spatial and temporal availability, and long well screens), one cannot make robust estimates of the mass distribution in the tracer plume, of the dilution index, or of second moments (from which dispersion coefficients are derived). However, some semi-quantitative estimates of the variation of flow velocity with depth, of dilution, and of dispersion can be made based on closer examination of the tracer curves. For instance, these data exemplify the utility of noble gas tracers for delineation of fast flow paths. Mass balance considerations rule out the possibility that a major portion of the groundwater flows at a rate of several meters per year. Wells that showed early tracer arrivals reaching the highest concentrations, are those with the shallowest sampling intervals (top-of-screens). Tracer was not detected at wells with the deepest top-of-screens. Furthermore, a drop in tracer levels occurs during times of high production and a rise occurs during times of low production (Figure 7), indicating that when water rises in the wellbore, a zone of higher tracer concentration is intercepted.

These observations suggest that a zone of preferential flow is likely present at a shallow depth. In this unconfined aquifer, such a fast path may exist at or near the phreatic surface. In contrast to the very fast movement of the small volume of water containing tracer, groundwater ages measured by the Tritium- ${ }^{3}$ Helium method give mean ages (residence times for water since recharge) in the AHF sub-basin of 3 to 9 years (Figure 2 and Table 1). Therefore, while the bulk of the water resides in the sub-basin for several years, a high conductivity layer near the water table likely provides a path for much faster transport for a small fraction of the artificially recharged water.

\section{CONCLUSIONS}

Tracers enriched in different isotopes of Xenon have several properties that make them ideal for tagging relatively large volumes of water at facilities used for public drinking water supply. Dissolved noble gases behave conservatively in the saturated zone, there is no health risk to drinking water supplies, the sensitivity achieved during dilution with ambient groundwater is excellent, and multiple recharge sources can be traced in a single experiment. Results from a tracer experiment at a California water district suggest that infiltration through artificial recharge ponds is focused along the shallow walls of the ponds, which are relatively free of impermeable sediments. A small fraction of tracer moved from the ponds through the thick, unconfined, coarse-grained alluvial aquifer to high capacity production wells at a horizontal velocity of $6 \mathrm{~m} /$ day. In contrast, mean water residence times indicate that the average rate of transport is 0.5 to $1 \mathrm{~m} / \mathrm{day}$. The results of this experiment show that enriched noble gas tracers can be used to delineate high conductivity 'fast paths' in heterogeneous media. 


\section{ACKNOWLEDGMENTS}

Special thanks go to the staff at ACWD and to Lee Davisson, Gail Eaton, Wayne Culham and Joan Beiriger at LLNL for the planning and execution of this experiment. This work was performed under the auspices of the US Department of Energy by the University of California, Lawrence Livermore National Laboratory under contract W7405-Eng-48.

\section{APPENDIX. REFERENCES}

Asano, T. (1993). "Proposed California Regulations for groundwater recharge with reclaimed municipal wastewater." Wat. Sci. Tech., 27, 157-164.

Ekwurzel, B., Schlosser, P., Smethie, W.M., Plummer, L.N., Busenberg, E., Michel R.L., Weppernig, R., and Stute, M. (1994). "Dating of shallow groundwater Comparison of the transient tracers ${ }^{3} \mathrm{H} /{ }^{3} \mathrm{He}$, chlorofluorocarbons, and ${ }^{85} \mathrm{Kr}$. " Water Resour. Res., 30, 1693-1708.

Gerba, C.P., (1999). "Virus survival and transport in groundwater." J. Industrial microbiology \& biotechnology, 22, 535-539.

Leblanc D.R., Garabedian S.P., Hess K.M., Gelhar L.W., Quadri R.D., Stollenwerk K.G., and Wood, W.W. (1991). "Large-scale natural gradient tracer test in sand and gravel, Cape-Cod, Massachusetts .1. Experimental design and observed tracer movement." Water Resour. Res., 27, 895-910.

MacFarlane, D.S., Cherry, J.A., Gillham, R.W., and Sudicky, E.A. (1983). "Migration of contaminants in groundwater at a landfill; a case study; 1, Groundwater flow and plume delineation." J. of Hydro., 63, 1-29.

MacKay, D.M., Freyberg, D.L., Roberts, P.V., and Cherry, J.A. (1986). "A Natural gradient experiment on solute transport in a sand aquifer. I: Approach and overview of plume movement. "Water Resour. Res., 22, 2017-2029.

Sanford, W.E., Shropshire, R.G., and Solomon, D.K. (1996). "Dissolved gas tracers in groundwater - simplified injection, sampling, and analysis." Water Resour. Res, $32,1635-1642$.

Schlosser, P., Stute, M., Dorr, H., Sonntag, C., and Munnich, O. (1988). "Tritium/3 ${ }^{3} \mathrm{He}$ dating of shallow groundwater." Earth, Planet. Sci. Lett., 89, 353-362.

Solomon, D.K., Poreda, R.J., Schiff, S.L., and Cherry, J.A. (1992). "Tritium and helium- 
3 as groundwater age tracers in the Borden aquifer." Water Resour. Res., 28, 741755 .

Warner, J.W., Gates, T.K., Namvargolian, R., Miller, P., and Comes, G. (1994). "Sediment and microbial fouling of experimental groundwater recharge trenches." J. Contaminant Hydro., 15, 321-344. 


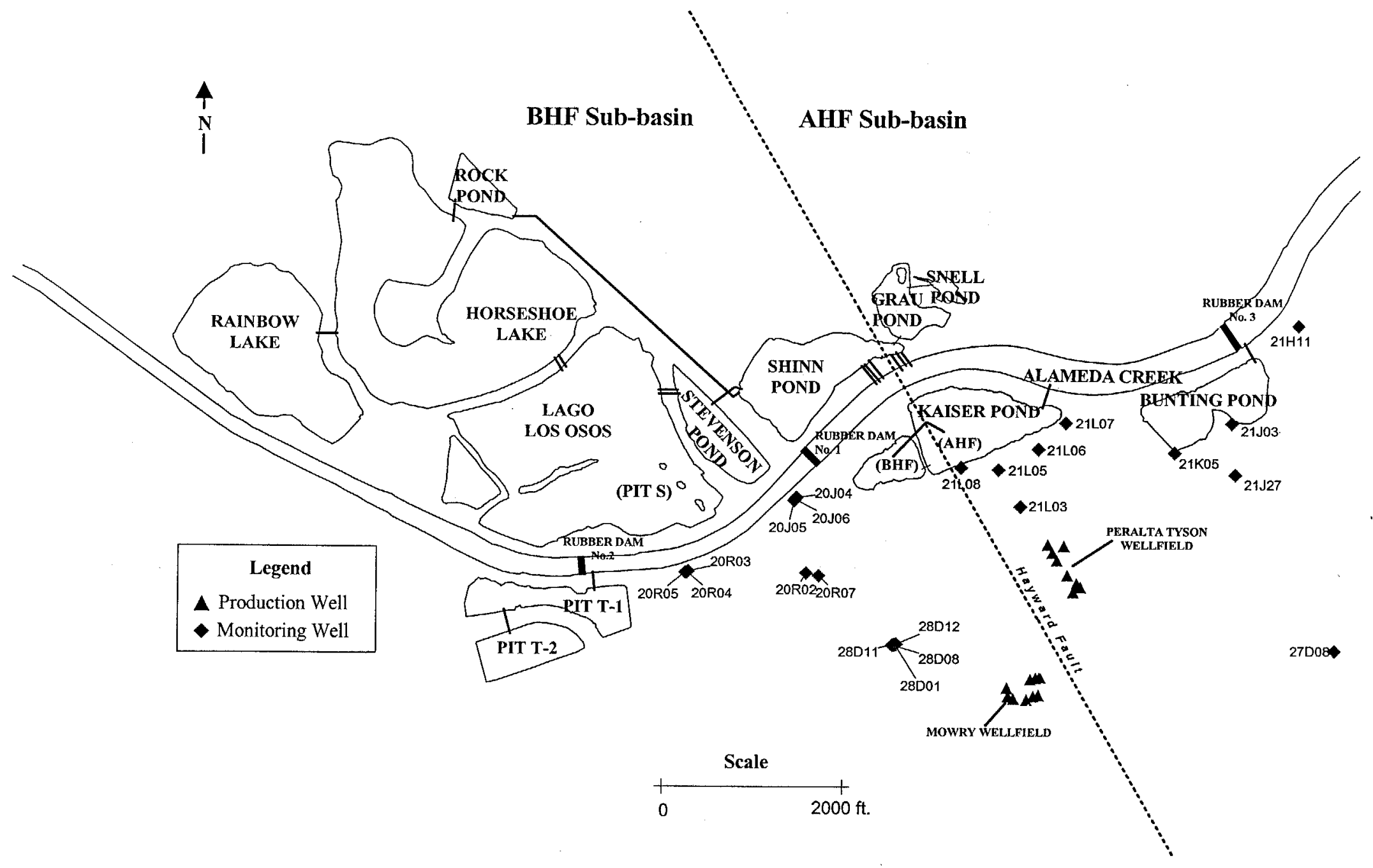

Figure 1. Plan-view of the ACWD recharge ponds and well fields. 


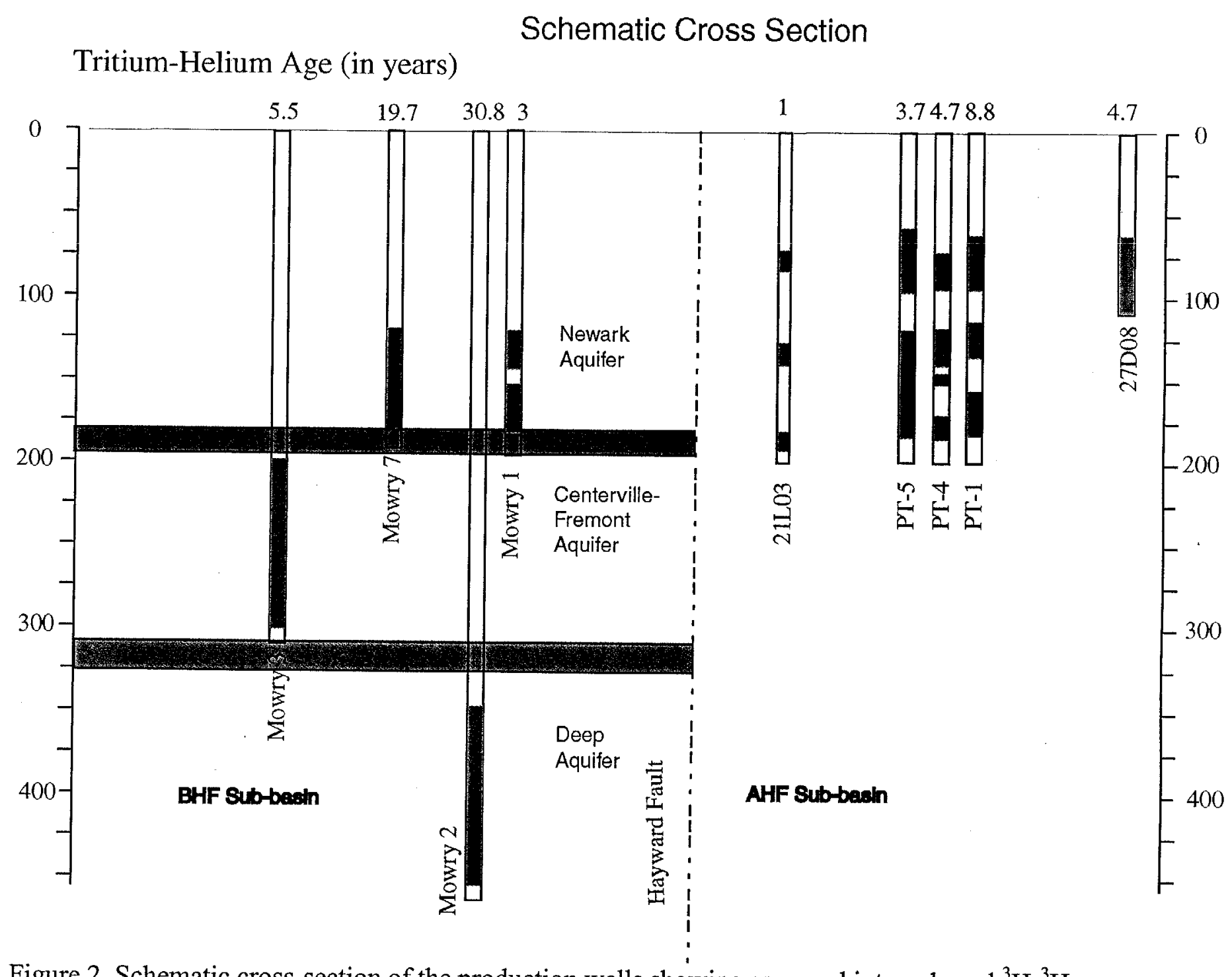

Figure 2. Schematic cross-section of the production wells showing screened intervals and ${ }^{3} \mathrm{H}-{ }^{3} \mathrm{He}$ ages 


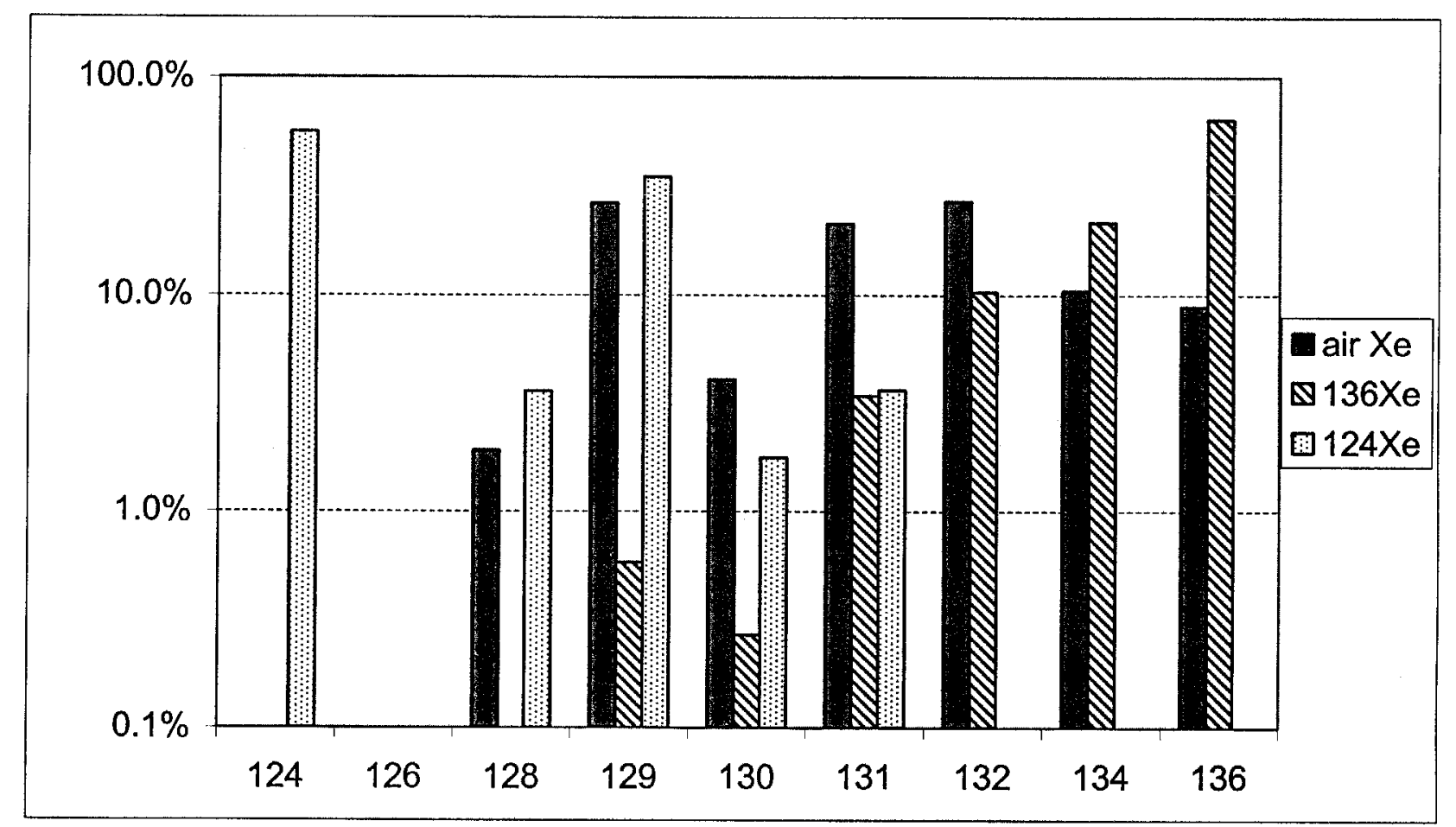

Figure 3. Relative abundances of the nine stable Xe isotopes. The dotted bars give the composition of the ${ }^{124} \mathrm{Xe}$ tracer (note that significant ${ }^{129} \mathrm{Xe}$ is also present). The crosshatched bars give the composition of the ${ }^{136} \mathrm{Xe}$ tracer. Atmospheric Xe is shown in the solid gray bars. 

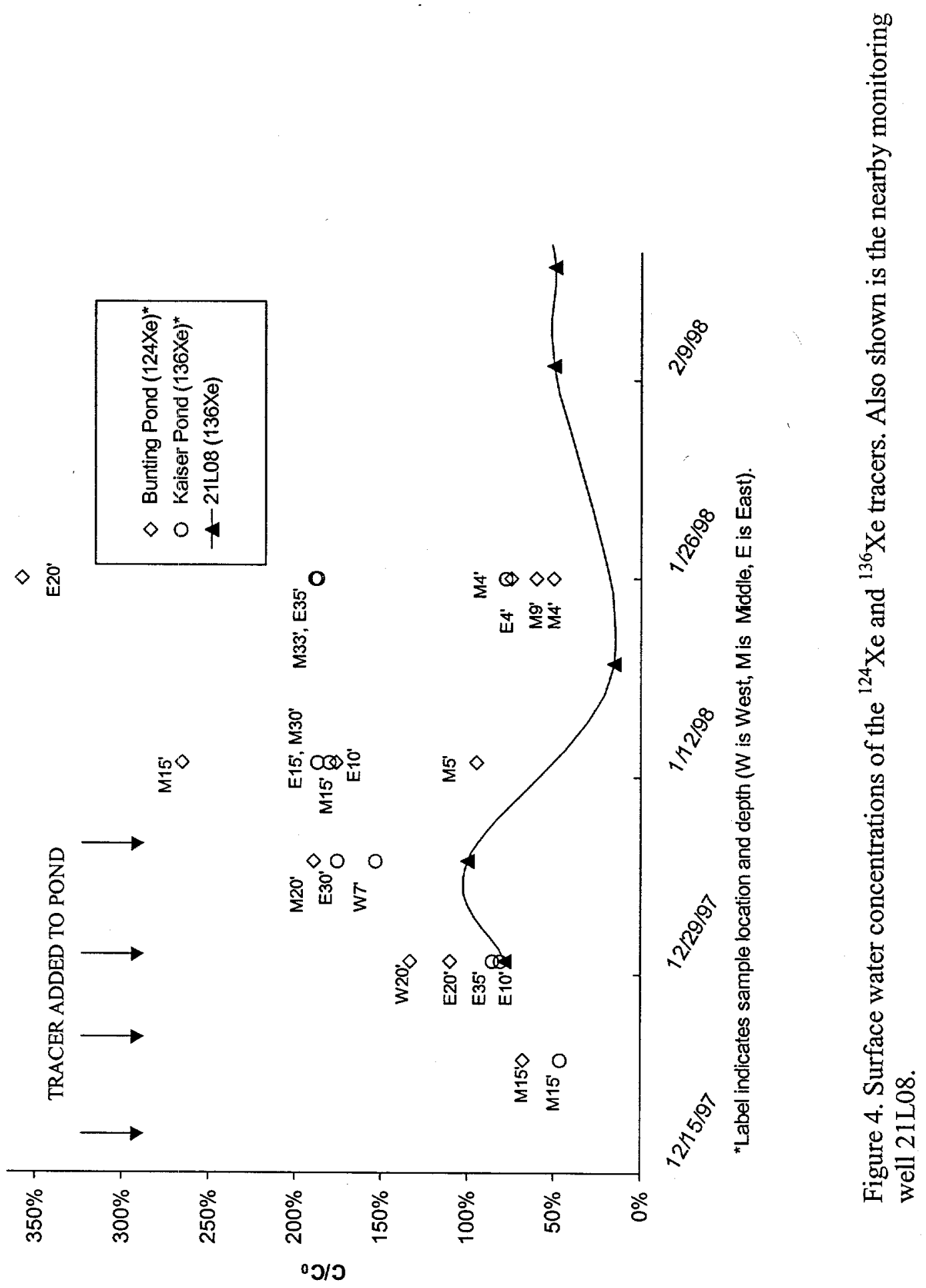


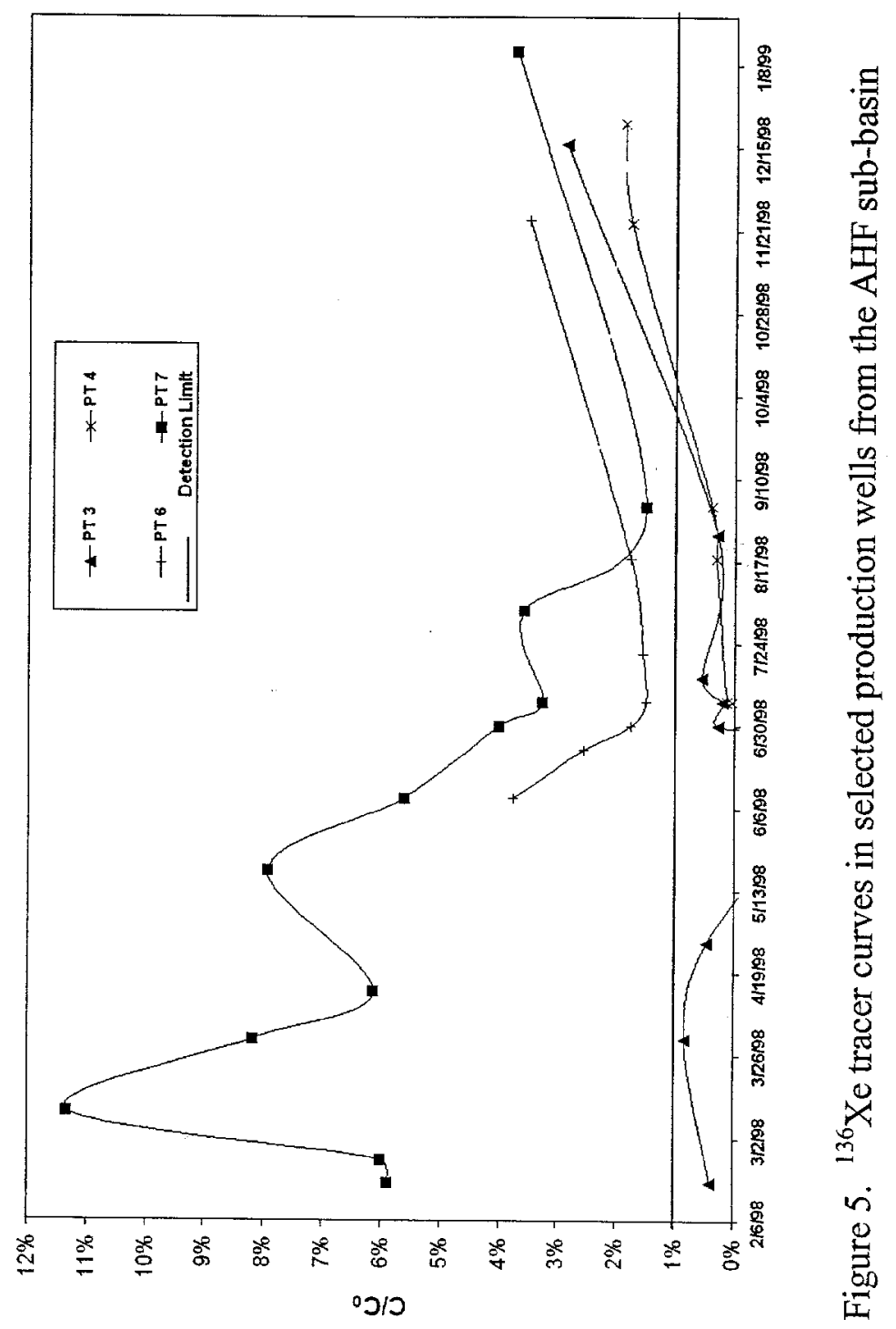




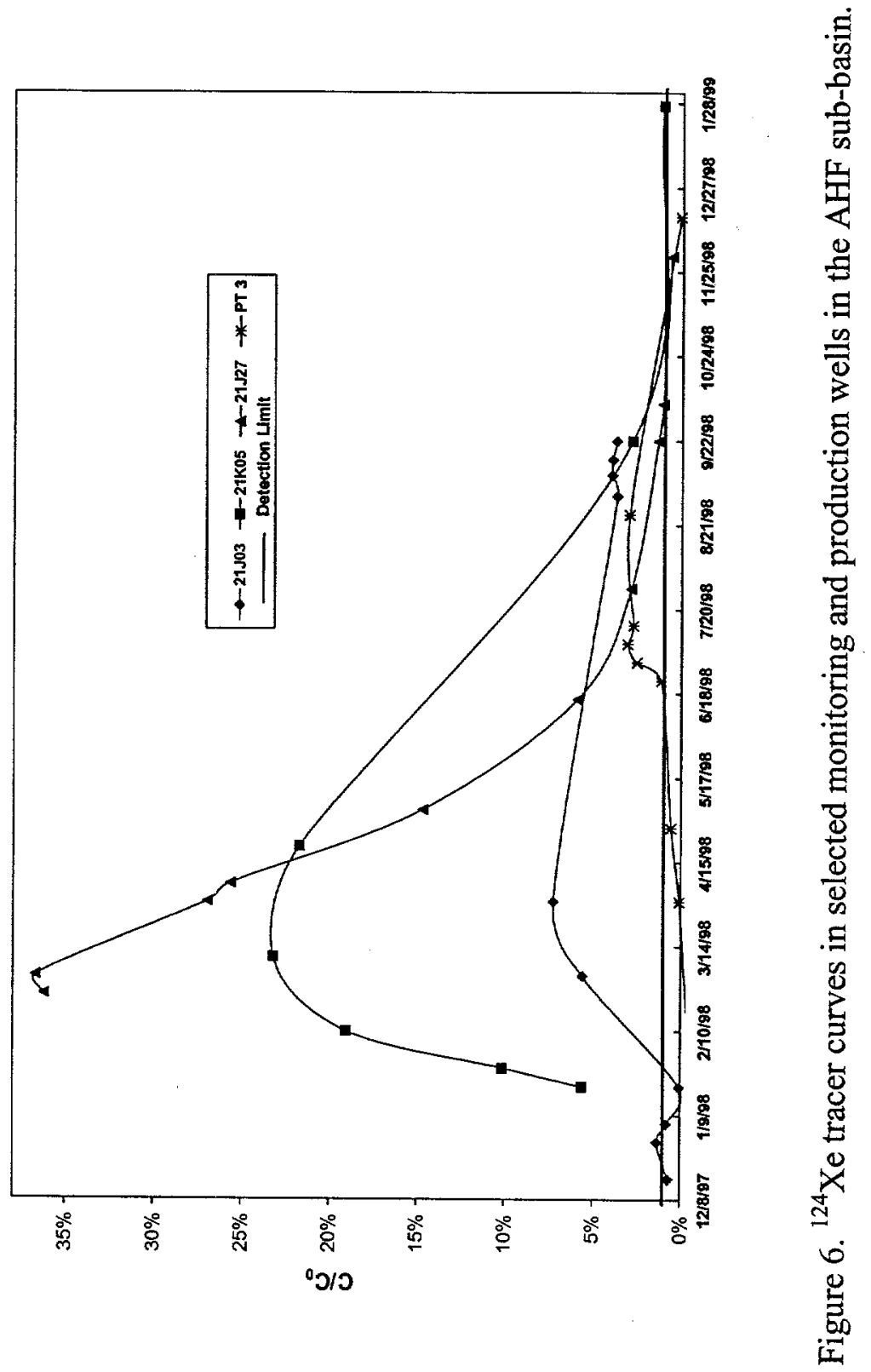




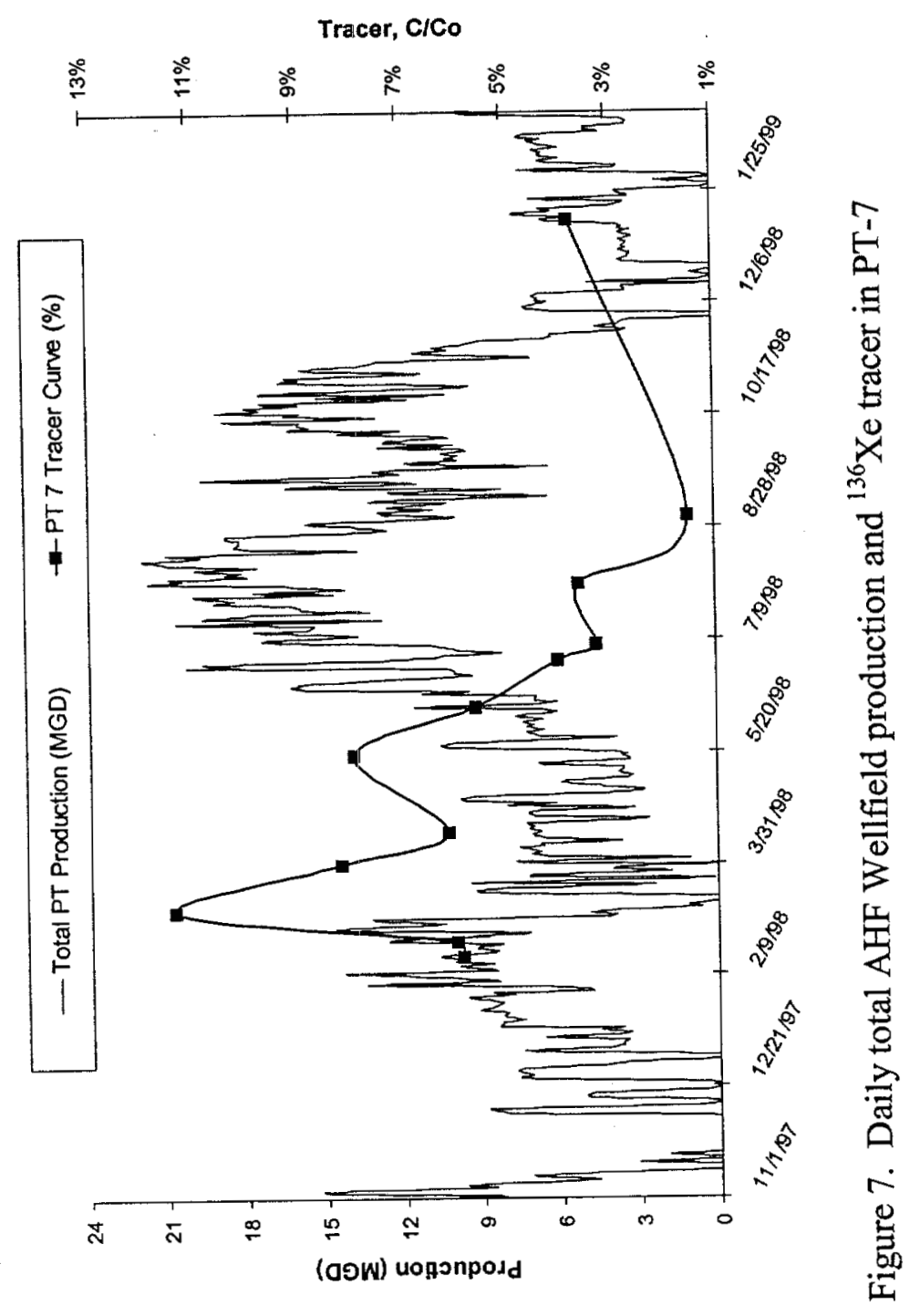


Table 1. Groundwater ages and tracer travel data

\begin{tabular}{|c|c|c|c|c|c|c|c|c|c|}
\hline Well & ${ }^{3} \mathrm{H} /{ }^{3} \mathrm{He}$ Age & Distance & Fir & rrival & ${ }^{136} \mathrm{Xe}^{\prime}$ & cer Travel Rate & Pea & rrival & Tracer Peak Travel Rate \\
\hline & years & $\mathrm{m}$ & & days & & (m/day) & & days & $\mathrm{m} /$ day \\
\hline PT-3 & & 488 & & 105 & & 4.6 & & 365 & 1.3 \\
\hline PT-4 & 9 & 543 & & 303 & & 1.8 & & 371 & 1.5 \\
\hline PT-5 & 4 & 427 & $<$ & 196 & $>$ & 2.2 & & 350 & 1.2 \\
\hline PT-6 & 4 & 396 & $<$ & 175 & $>$ & 2.3 & & 175 & 2.3 \\
\hline PT-7 & 5 & 366 & $<$ & 63 & $>$ & 5.8 & & 84 & 4.4 \\
\hline Mowry 1 & 9 & 823 & & 230 & & 3.6 & & 230 & 3.6 \\
\hline Mowry 7 & 6 & 823 & & 230 & & 3.6 & & 230 & 3.6 \\
\hline Mowry 2 & 31 & & & N/A & & & & & \\
\hline Mowry 3 & 20 & & & N/A & & & & & \\
\hline $21 \mathrm{LO5}$ & & 64 & & 21 & & 3.0 & $<$ & 98 & 0.7 \\
\hline $21 \mathrm{LO} 6$ & & 58 & & 21 & & 2.8 & & 42 & 1.4 \\
\hline $21 \mathrm{LO} 07$ & & 24 & $<$ & 13 & $>$ & 1.8 & & 35 & 0.7 \\
\hline $21 \mathrm{LO} 08$ & & 12 & $<$ & 13 & $>$ & 0.9 & & 21 & 0.6 \\
\hline & & & & & ${ }^{124} \mathrm{X}$ & $\begin{array}{l}\text { acer Travel Rate } \\
(\mathrm{m} / \mathrm{day})\end{array}$ & & & \\
\hline PT-1 & 9 & 585 & $<$ & 168 & $>$ & 3.5 & & 168 & 3.5 \\
\hline PT-3 & & 552 & & 135 & & 4.1 & & 203 & 2.7 \\
\hline PT-4 & 9 & 558 & $<$ & 203 & $>$ & 2.7 & & 203 & 2.7 \\
\hline PT-5 & 4 & 539 & $<$ & 196 & $>$ & 2.8 & & 260 & 2.1 \\
\hline $21 \mathrm{~J} 03$ & & 15 & & 13 & & 1.2 & & 105 & 0.1 \\
\hline $21 \mathrm{~K} 05$ & & 9 & & 30 & & 0.3 & & 84 & 0.1 \\
\hline $21 \mathrm{~J} 27$ & & 162 & $<$ & 70 & $>$ & 2.3 & & 77 & 2.1 \\
\hline
\end{tabular}

